\title{
O Ensino da Clínica Ampliada na Atenção Primária À Saúde: Narrativas como a Expressão das Percepções e Vivências de Alunos de Graduação Médica.
}

\author{
Godoy, Daniele Cristina; Cyrino, Antonio de Padua P.; Pavan, Mariana \\ Faculdade de Medicina Unesp Botucatu — dani.god@uol.com.br
}

Escolas médicas têm passado por transformações na busca de impactar os problemas da atual medicina tecnológica, sendo o principal deles a desumanização da prática. no Brasil após a criação de um sistema único de saúde (SUS) as escolas têm sido provocadas a adaptarem-se as necessidades deste sistema. Neste processo de mudança é importante citarmos o papel fundamental das Diretrizes Curriculares Nacionais e o papel indutivo dos Ministérios da Saúde e Educação que numa interlocução lançaram programas de incentivo a reestruturação do ensino na área da saúde. Escolas médicas selecionadas a participarem de tais programas promovem reformas curriculares no sentido de reorientar a formação centrada em competências técnicas para a formação de profissionais com vivência sobre a universalidade, a qualidade e humanização na Atenção Primária à Saúde, resultando em integração entre a formação e os serviços de saúde, bem como com as reais necessidades de saúde da população. a escola medica, campo desta pesquisa, selecionada a participar do PROMED (Projeto de Incentivo a Mudanças Curriculares para o Curso de Medicina) elaborou em 2002 o Programa Interação Universidade Serviços e Comunidade (IUSC), hoje uma disciplina, dirigida aos cursos de medicina e enfermagem que acontece em cenários de ensino-aprendizagem junto a comunidade, utilizando na sua prática metodologias ativas e inovações pedagógicas. o presente estudo tomou como campo a disciplina IUSC III dirigida ao $3^{\circ}$ ano de graduação médica, que tem como atividade principal a consulta médica supervisionada orientada pelas concepções de humanização e integralidade do cuidado, tendo o ensino da Clínica Ampliada como proposta pedagógica. a estratégia de avaliação utilizada é o diário de campo para o registro pelo aluno das atividades realizadas com suas dificuldades, facilidades e reflexões. Tendo este diário como fonte documental, o objetivo da pesquisa foi reconhecer as percepções e vivências de alunos, com relação ao aprendizado da Clínica Ampliada na Atenção Primária a Saúde. Tratou-se de um estudo de natureza qualitativa e documental, no qual se fez uma análise temática de conteúdo dos registros dos diários, ou seja, as narrativas dos alunos que cursaram a disciplina nos anos de 2009 e 2010. na análise das narrativas identificouse os eixos temáticos que se referem às percepções e vivências do aluno com relação à: unidade de saúde e sua equipe; o processo ensino-aprendizagem; a vivência clínica e a relação alunopaciente. o estudo nos permitiu reconhecer o diário como um potente instrumento no processo de ensino-aprendizagem, dada a riqueza de seu conteúdo nas esferas afetiva, pedagógica e comunicacional e acompanhar a aprendizagem do aluno na disciplina referente a sua apreensão sobre aspectos que fundamentam a Clínica Ampliada e a consulta clínica baseada na integralidade e humanização do cuidado.

Godoy, Daniele Cristina; Cyrino, Antonio de Padua P.; Pavan, Mariana. O Ensino da Clínica Ampliada na Atenção Primária À Saúde: Narrativas como a Expressão das Percepções e Vivências de Alunos de Graduação Médica.. In: Anais do Congresso Internacional de Humanidades \& Humanização em Saúde [= Blucher Medical Proceedings, num.2, vol.1]. São Paulo: Editora Blucher, 2014. ISSN 2357-7282

DOI 10.5151/medpro-cihhs-10351 